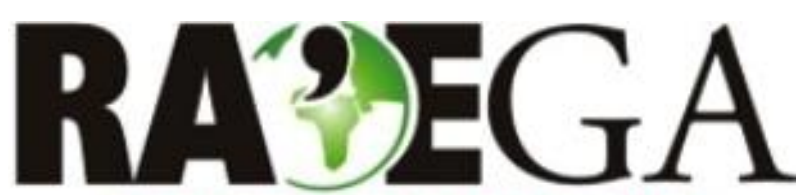

O ESPAÇO GEOGRÁFICO EM ANÁLISE

\title{
LINEAR SPECTRAL MIXING MODEL APPLIED IN IMAGES FROM PROBA-V SENSOR: A SPATIAL MULTIRESOLUTION APPROACH
}

\section{MODELO LINEAR DE MISTURA ESPECTRAL APLICADO EM IMAGENS DO SENSOR PROBA-V: UMA ABORDAGEM MULTIRRESOLUÇÃO ESPACIAL}

\author{
Andeise Cerqueira Dutra ${ }^{1}$, Yosio Edemir Shimabukuro ${ }^{1}$, Egidio Arai $^{1}$
}

\begin{abstract}
The complexity of pixel composition of orbital images has been commonly referred to the spectral mixture problem. The acquisition of endmembers (pure pixels) direct from image under study is one of the most commonly employed approaches. However, it becomes limited in low or moderate spatial resolutions due to the lower probability of finding those pixels. In this way, this work proposes the combined use of images with different spatial resolutions to estimate the spectral responses of the endmembers in low spatial resolution image, from the obtained proportions derived from the spatial higher-resolution images. The proposed methodology was applied to products provided by PROBA-V satellite with spatial resolution of $100 \mathrm{~m}$ and $1 \mathrm{~km}$ in the Pantanal region of Mato Grosso state. Initially, the fraction images (proportions) were generated from the $100 \mathrm{~m}$ dataset using the endmembers selected directly in the image, considering the higher probability of finding pure pixels in such images. Following the spectral responses of the endmembers in $1 \mathrm{~km}$ were estimated by multiple linear regression, using the proportions of the endmembers in the pixels derived from $100 \mathrm{~m}$ images. For the evaluation, the endmembers fraction images were compared and field data was used. These analyses indicated that the spectral responses estimated allowed to improve the results with regard to error, to variability, and to the identification of endmembers proportions, considering that inadequate choice of pixels considered as pure in low spatial resolution images can affect the quality of the fraction images for operational use.
\end{abstract}

Keywords: Estimated Endmembers; Moderate Spatial Resolution; Linear Regression; Regional Scale; Pantanal.

\section{RESUMO}

A complexidade da composição de um pixel nas imagens orbitais tem sido comumente referida ao problema de mistura espectral. A aquisição de endmember (pixel puro) a partir da própria imagem em estudo é uma das abordagens mais comumente empregadas, entretanto, torna-se limitada em sensores de baixa ou moderada resolução espacial pela menor probabilidade de encontrar tais pixels. Dessa maneira, este trabalho propõe o uso combinado de imagens de diferentes resoluções espaciais para estimar as respostas espectrais dos endmembers na imagem de baixa resolução espacial a partir das proporções obtidas nas imagens de maior resolução espacial. $O$ método proposto foi aplicado nos produtos fornecidos do minissatélite PROBA-V com resolução espacial de $100 \mathrm{~m}$ e $1 \mathrm{~km}$ na região do Pantanal Mato Grossense. Inicialmente, as imagens fração (proporções) foram geradas para os dados de $100 \mathrm{~m}$ utilizando os endmembers da própria imagem considerando a maior probabilidade de encontrar pixels puros nestas imagens. A seguir, as respostas espectrais dos endmembers nos dados de $1 \mathrm{~km}$ foram estimadas por regressão linear múltipla considerando que as proporções dos endmembers nos pixels são derivadas das imagens de $100 \mathrm{~m}$. Para avaliação, foram comparadas as imagens fração e utilizados dados de campo. Conclui-se que as respostas espectrais estimadas permitiram a melhoria dos resultados no que se refere ao erro, à variabilidade e à identificação das proporções dos endmembers, visto que a escolha indevida de pixels considerados como puros em produtos de baixa resolução espacial pode afetar a qualidade das imagens fração para uso operacional.

Palavras chave: Endmembers estimados; Moderada Resolução Espacial; Regressão Linear; Escala Regional; Pantanal.

\footnotetext{
${ }^{1}$ National Institute for Space Research (INPE). emails: \{andeise.dutra, yosio.shimabukuro, egidio.arai\}@inpe.br
} 


\section{LINEAR SPECTRAL MIXING MODEL APPLIED IN IMAGES FROM PROBA-V SENSOR: A SPATIAL MULTIRESOLUTION APPROACH}

\section{INTRODUCTION}

In recent decades, great amount of data with different spectral, temporal and spatial resolutions have been made available to the Remote Sensing user community. In Earth observation studies, a wide range of applications requires accurate estimates. Therefore, high and medium spatial resolution sensor products are used. However, the use of these products may be limited by the lower frequency of revisit (LI et al., 2017; HILKER et al., 2009; WULDER et al., 2008), which may be further affected by the incidence of clouds (ZHU; WOODCOCK, 2014; ASNER, 2001). Furthermore, due to the storage capacity or download data onboard of the high spatial resolution sensors, some parts of the globe may not be continuously imaged by certain sensors. On the other hand, low and moderate spatial resolution sensors may provide observation products of the globe in more frequent revisits due to its wide viewing range coverage (ZHANG et al., 2017). However, it is also emphasized the challenge in studies whose object of interest is smaller than the pixel size (BARET et al., 2013).

This problem occurs because the radiance detected by the sensor is an integrated sum of the radiance of all objects or materials contained within the instantaneous field of view (IFOV), for example, shade, soil and canopy of trees. Thus, each pixel provides the result of the interaction of electromagnetic radiation with multiple components, do not representing the composition of a single object only (SHIMABUKURO et al., 2014). Thus, the complexity of a pixel composition has commonly been referred as the spectral mixture (SHIMABUKURO; PONZONI, 2017; SHIMABUKURO; SMITH, 1995).

Several mathematical models have been proposed to identify the mixing proportion of the pixel (KESHAVA; MUSTARD, 2002; GARCIA-HARO et al., 2005; ALCÂNTARA et al., 2008) and the linear spectral mixing model (LSMM) proposed by Shimabukuro and Smith (1991) is one of the most commonly used techniques. As a result of the LSMM, fraction images are generated containing information about the proportion of the components contained in each pixel, which in turn are widely used, as example, in studies of land cover changes (ADAMI et al., 2018) and monitoring of deforestation and forest degradation (SHIMABUKURO et al., 2019). In the Pantanal, the technique has also been used in the monitoring of land cover dynamics (SHIMABUKURO et al., 1998), in the characterization of the types of coverage using hyperspectral data (GALVÃO et al., 2003), in the study of flooding from MODIS images (PADOVANI et al., 2009), and in the assessment of grassland degradation (RAVAGLIA et al., 2010).

The application of the LSMM is possible with a priori knowledge of the spectral response of the reference components, and one of the most commonly used approaches to the application of the model is to acquire pure pixels or endmembers from the spectral reflectance of the components available directly in the image study (SHIMABUKURO; PONZONI, 2017). In high and medium spatial resolution images, it is assumed that there is a higher probability of finding pure pixels or pixels that include a single reference component available in the image. However, in moderate and low spatial resolution images, the mixed nature of pixels limits this approach because of the difficulty or even the impossibility of obtaining pure pixels (DE FREITAS et al., 2008). Particularly in global or regional scale studies, the determination of these endmembers remains a challenge (MEYER; OKIN, 2015).

With the growing amount of available products, previous studies have demonstrated the ability to fuse different resolutions and observations sensors as a promising way to increase the potential of Earth observation studies (LI et al., 2017; DE FREITAS et al., 2008). In this context, the objective of this work is to propose a method using linear spectral mixing model to explore the combination of images of different spatial resolutions and then, extend the information contained in fraction images on a local scale to larger areas. Thus, this proposal aims to estimate the spectral responses of endmembers in low spatial resolution images, 


\section{LINEAR SPECTRAL MIXING MODEL APPLIED IN IMAGES FROM PROBA-V SENSOR: A SPATIAL MULTIRESOLUTION APPROACH}

from the obtained proportions of the higher spatial resolution images.

\section{MATERIAL AND METHODS}

\subsection{Study area}

The Pantanal covers an area of approximately $138,183 \mathrm{~km}^{2}$ between the states of Mato Grosso and Mato Grosso do Sul (SILVA; ABDON, 1998). As the study area for this work, it was more specifically adopted the portion of the Pantanal biome encompassed by the Mato Grosso state (Figure 1).
The vegetation of the biome is influenced by the predominance of Savanna and remnants of Chaco, by the Amazon Forest and Atlantic Forest (ADAMOLI, 1981), and by livestock as the main anthropic activity. In addition to the association of different soil types and flood dynamics, the Pantanal presents itself as a complex and heterogeneous environment (HARRIS et al., 2005), which is the reason why it was adopted in this study.

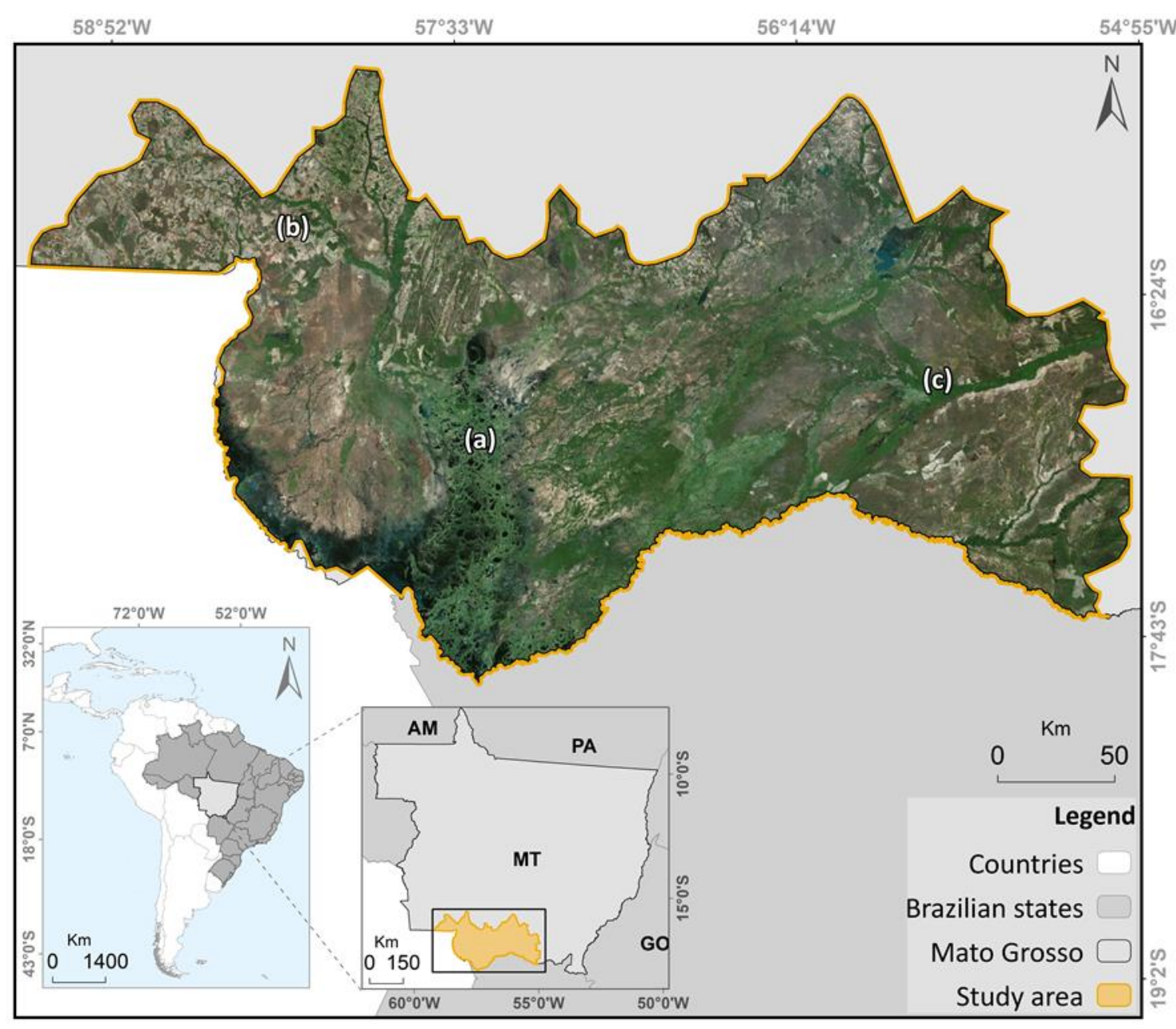

Figure 1 - Location of the Pantanal of Mato Grosso (MT) state as study area, highlighting (a) flood areas, (b) agriculture, and (c) natural vegetation formations. Source: Esri World Imagery Basemap Service in true color.

The dynamics of flooding is strongly influenced by rainfall patterns, especially by alternating two well defined seasons: the rainy season, which occurs between October to April, and the dry season, which occurs from May to
September (SILICON-CALZADA et al., 2017) (Figure 2). Thus, targeting the applicability of the proposed method in different periods, the months of February and August were selected for having the maximum and minimum monthly 
precipitation $(\mathrm{mm})$ observed for the year of study, respectively.

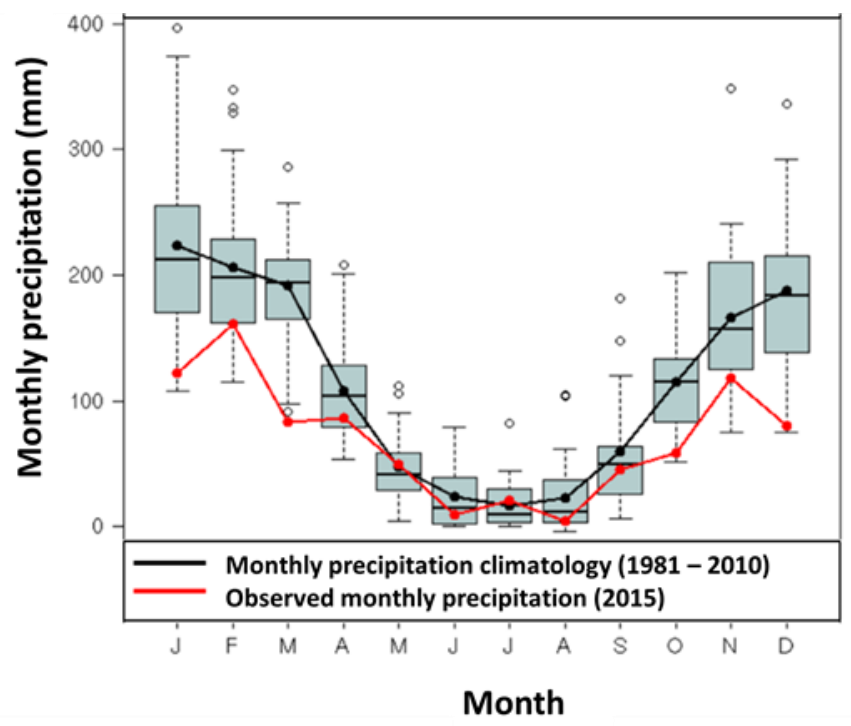

Figure 2 - Monthly precipitation climatology between 1981-2010 years and monthly precipitation observed for the 2015 year (adapted from CPTEC, 2014).

\subsection{Materials}

The PROBA-V (Project for On-Board Autonomy - Vegetation) is a mini-satellite launched in 2013, designed to ensure the 15-year continuity of the SPOT-Vegetation mission by the European Space Agency (ESA). To meet the user community needs, the four spectral bands of the sensor are similar to the SPOT-Vegetation instrument, available in: blue (centered at 0.463 $\mu \mathrm{m})$, red $(0.655 \mu \mathrm{m})$, near infrared $(0.837 \mu \mathrm{m})$, and middle infrared $(1.603 \mu \mathrm{m})$ (WOLTERS et al., 2018).
The products are distributed in the ESA image catalog on the platform <http://www.vitoeodata.be/>, atmospherically corrected and in different spatial resolution and temporal compositions (Table 1). For this work, they were acquired for the year 2015 in a five- and ten-days temporal composition at the top of the canopy (TOC) and with a spatial resolution of $100 \mathrm{~m}$ and $1 \mathrm{~km}$, respectively.

\begin{tabular}{cc}
\hline Spatial resolution & Temporal resolution \\
\hline $100 \mathrm{~m}, 300 \mathrm{~m}$ and $1 \mathrm{~km}$ & Daily \\
$100 \mathrm{~m}$ & 5 days composition \\
$300 \mathrm{~m}$ and $1 \mathrm{~km}$ & 10 days composition \\
\hline Table 1 - Summary of products available PROBA-V (WOLTERS et al, 2018).
\end{tabular}

Table 1 - Summary of products available PROBA-V (WOLTERS et al., 2018).

\subsection{Methods}

A linear relationship is used to represent the spectral mixture of the components contained in the pixel, i.e. the LSMM assumes that the spectral reflectance of a pixel can be obtained as a linear combination of the responses of each element taken as reference. Thus, each pixel contains information about the proportion and the spectral response of each component (SHIMABUKURO; SMITH, 1995).

Assuming this approach, it is understood then that being aware of the spectral response of each reference component, their proportions at the pixel can be obtained. Similarly, the proportions of the reference components are known, then their spectral responses can be 


\section{LINEAR SPECTRAL MIXING MODEL APPLIED IN IMAGES FROM PROBA-V SENSOR: A SPATIAL MULTIRESOLUTION APPROACH}

estimated (SHIMABUKURO; SMITH, 1995). Thus, the linear spectral mixing model proposed by Shimabukuro and Smith (1991) can be represented as:

$$
r_{i}=\Sigma\left(a_{i j} x_{j 1}\right)+\varepsilon_{i}
$$

where:

$r_{i}=$ Average spectral reflectance in the spectral band $\mathrm{i}$;

$a_{i j}=$ Spectral response of the $\mathrm{j}$ component of the mixture in the spectral band $\mathrm{i}$;

$x_{j}=$ Proportion of the component $\mathrm{j}$ at a pixel;

$\varepsilon_{i}=$ Error in the spectral band $\mathrm{i}$;

$i=1, \mathrm{n}$ (number of spectral bands used);

$j=1, \mathrm{~m}$ (number of considered components).

The result of equation (1) is subject to constraints, which in turn, must be satisfied with the sum of proportions equal to one and nonnegative values:

$$
0 \leq x_{j} \leq 1
$$

For implementation of the proposed method (Figure 3), firstly (step 1), the temporal composition adjustment of the PROBA-V products was performed, since both have different temporal compositions. For this, the products can be combined using the Maximum Value Composition, which selects the maximum values of NDVI (Normalized Difference Vegetation Index) of each pixel among all observations, as mentioned by Wolters et al. (2018). With this technique, the NDVI for the 100 $\mathrm{m}$ products available in the temporal composition of five days were calculated, and the maximum values between two five-days temporal compositions were selected. Thus, the data of $100 \mathrm{~m}$ spatial resolution had a ten-day temporal composition similar to that of $1 \mathrm{~km}$ spatial resolution data.

$$
\Sigma x_{j}=1
$$

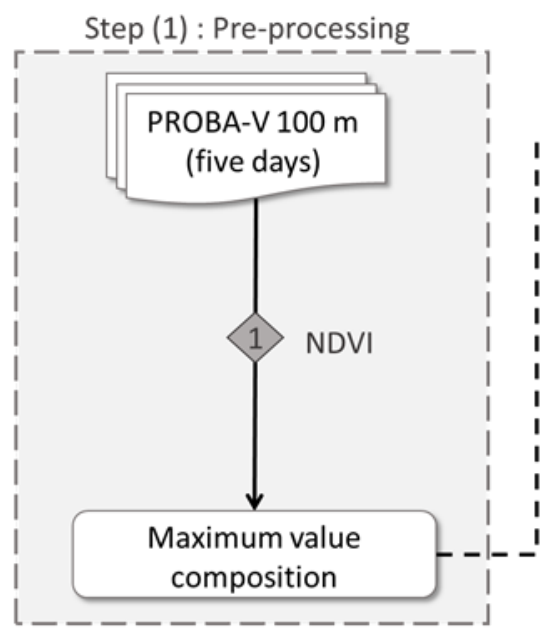

Step (2) : Estimating spectral responses

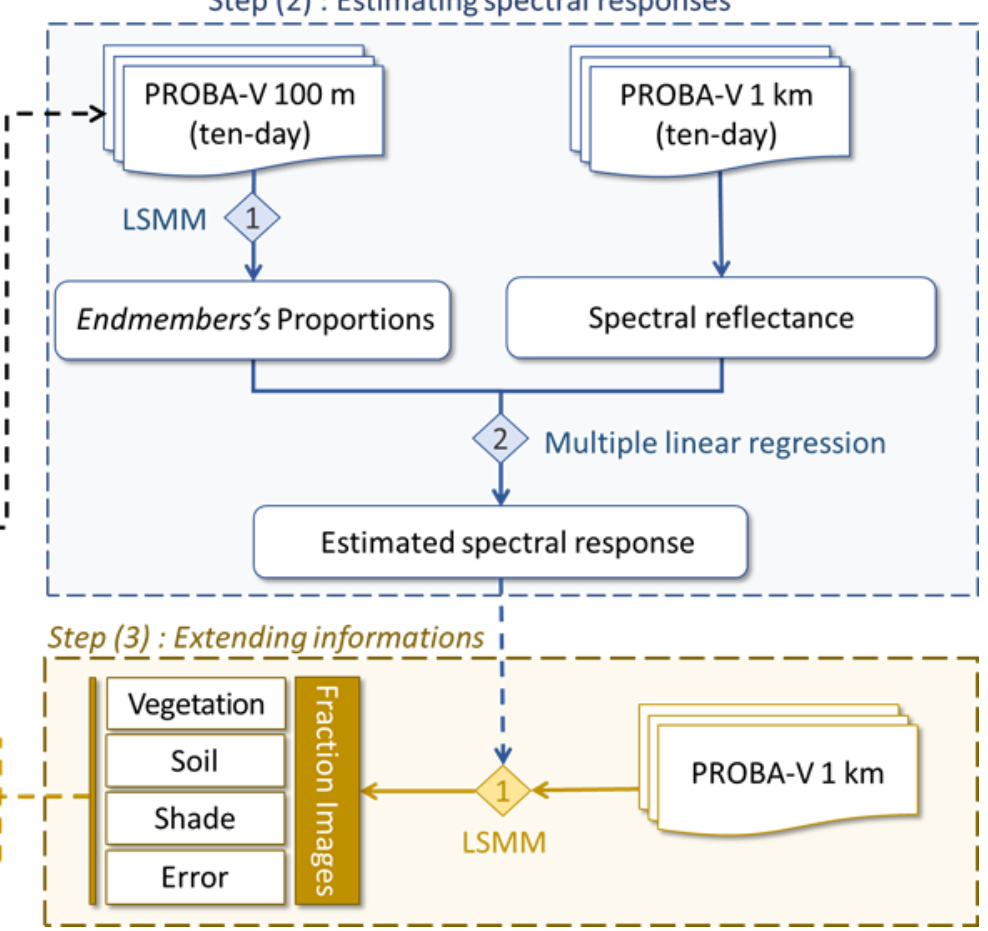

Figure 3 - Methodological flowchart. 
As step (2) the LSMM in this study was used to calculate the proportions of each component in the $100 \mathrm{~m}$ images from the available spectral response in the study image. Employing the approach of pure pixels selected according to the spectral response, three components in the pixel assumed as reference were considered, which correspond to vegetation, soil, and shade (Figure 4). As a result of the LSMM, fraction images were obtained for each component considered in the pixel, which represents the proportion in the original data.

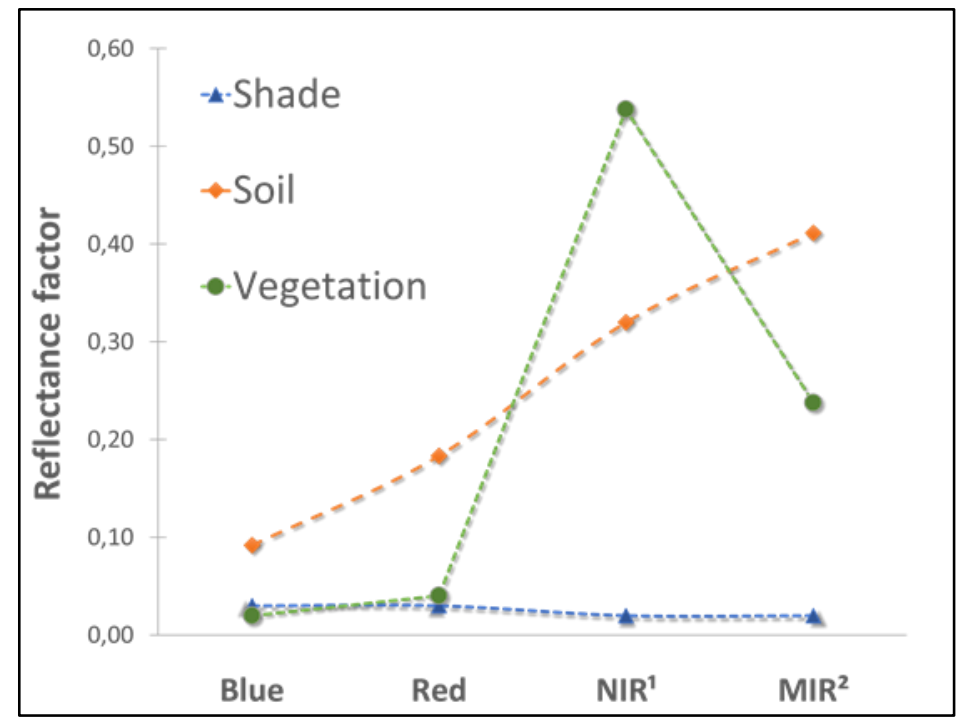

Figure 4 - Spectral response of the reference components obtained in the study image. Where NIR ${ }^{1}-$ Near Infrared; MIR ${ }^{2}$ - Middle Infrared.

Assuming that the proportions of the components $\left(x_{j}\right)$ extracted from the fraction images derived from the LSMM applied to higher spatial resolution image are known, for this work it was adopted the mathematical model proposed by Richardson et al. (1975) to estimate the spectral response of the components. The model was developed to partition the spectral reflectance $\left(r_{i}\right)$ in spectral reflectance of the component $\left(a_{i j}\right)$, in which $j=1$ represents the vegetation component, $j=2$ represents the soil component and $j=3$ represents the shade component. The model can be written as:

$$
r_{i}=a_{i 1} x_{1}+a_{i 2} x_{2}+a_{i 3}\left(1-x_{1}-x_{2}\right)
$$

where:

$r_{i}=$ Average spectral reflectance in all spectral bands;

$a_{i j}=$ Spectral reflectance of components to be estimated;

$i=$ Spectral bands of the sensor used; $j=$ Established components, which vegetation (1), soil (2) and shade (3);

$x_{j}=$ Known reference proportions of the components;

Rewriting the above equation, it is obtained:

$$
r_{i}=a_{i 3}+\left(a_{i 1}-a_{i 3}\right) x_{1}+\left(a_{i 2}-a_{i 3}\right) x_{2},
$$

Similar to the multiple linear regression equation:

$$
r_{i}=A_{0}+A_{1} x_{1}+A_{2} x_{2}
$$

Thus, since the proportions were obtained, they become the input variables in equation (5) with the average spectral reflectance in all spectral bands of low spatial resolution image. Thus, the combination of products with different spatial resolutions allows the determination of the spectral response of 


\section{LINEAR SPECTRAL MIXING MODEL APPLIED IN IMAGES FROM PROBA-V SENSOR: A SPATIAL MULTIRESOLUTION APPROACH}

vegetation $\left(A_{0}\right)$, soil $\left(A_{0}+A_{1}\right)$ and shade $\left(A_{0}+A_{2}\right)$ components. Assuming that the sum of the proportions is equal to one, in this case is not necessary to add the shade proportion as the input parameter of the model.

In this step (2), 25 samples were collected in the study area in the same geographical coordinates and without the incidence of clouds for wet and dry seasons in both products. For this, it was considered that a pixel of $1 \mathrm{~km}$ corresponds to eighty-one pixels in the product of $100 \mathrm{~m}$, due to variations in cartographic conversion for geometric projection, each pixel had the spatial resolution of $0.008929^{\circ}$ and $0.000992^{\circ}$, respectively (Figure 5).

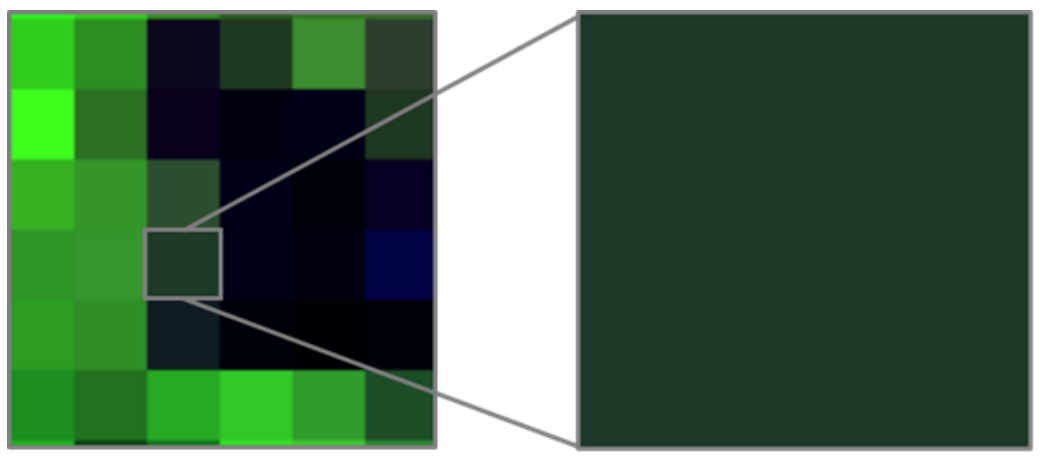

$1 \mathrm{~km}$

$1 \mathrm{~km}$

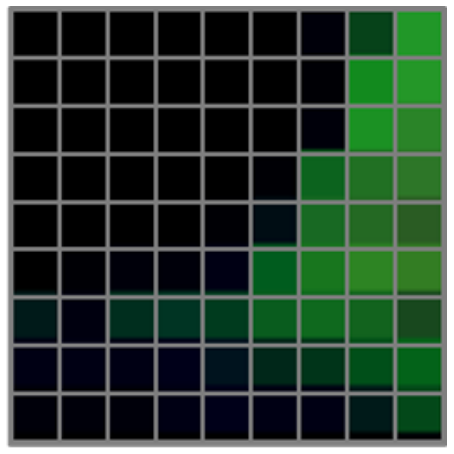

$100 \mathrm{~m}$

Figure 5 - Representation of a pixel composition at different spatial resolutions of PROBA-V, where $1 \mathrm{~km}$ $\left(0.008929^{\circ}\right)$ to the left and $100 \mathrm{~m}\left(0.000992^{\circ}\right)$ to the right, in false color composite of $\mathrm{R}(1.603 \mu \mathrm{m}) \mathrm{G}$ $(0.837 \mu \mathrm{m}) \mathrm{B}(0.655 \mu \mathrm{m})$.

Finally, in step (3) the LSMM was applied to $1 \mathrm{~km}$ PROBA-V image using the estimated spectral response of vegetation, soil and shade components. For comparative purposes, the LSMM was also applied to the same product using the spectral response of the reference components acquired in the image itself, referred by conventional approach.

\subsection{Validation of Results}

A field campaign was carried out in Mato Grosso in September 2018, a period which corresponds to the end of the dry season in the region, aiming to identify areas of forest, bare soil, and water bodies. The campaign also included the passage in the Pantanal of MatoGrosso state and flooded areas that due to the season could only be properly identified through information collected from neighborhood. At this step, control points were collected in the field using a GARMIN GPS (Global Positioning System) device connected to a notebook and plotted on a mosaic of OLI/Landsat-8 (Operational Land Imager) satellite images using the Global Mapper
(Global software Mapper Software LLC designs, Parker, CO) for navigation. All control points were collected after five seconds remaining in place and when at least five satellites signals were received by the device used. However, according to Caten et al. (2007), less than one minute in data collection can generate the average positional error of up to $5 \mathrm{~m}$. Thus, the influence of the GPS positioning error was disregarded for this work due to the spatial resolution of the sensor used.

Furthermore, georeferenced photographs were collected in the field campaign and used as auxiliary data for the visual interpretation of the targets.

\section{RESULTS AND DISCUSSION}

The estimated spectral responses for determining the reference components in the 1 $\mathrm{km}$ PROBA-V product in wet and dry seasons are shown in Tables 2 and 4. Also, the equation obtained from the multiple linear regression (equation 5) and the coefficient of determination 
DUTRA, A. C. et. al.

LINEAR SPECTRAL MIXING MODEL APPLIED IN IMAGES FROM PROBA-V SENSOR: A SPATIAL MULTIRESOLUTION APPROACH

in each spectral band adopted are shown in

Tables 3 and 5.

\begin{tabular}{ccccc}
\hline \multicolumn{5}{c}{ February 2015 } \\
\hline \multirow{2}{*}{ Endmembers } & Blue & Red & NIR $^{1}$ & MIR $^{2}$ \\
\cline { 2 - 5 } Shade & 0.02 & 0.02 & 0.06 & 0.03 \\
Soil & 0.09 & 0.18 & 0.22 & 0.41 \\
Vegetation & 0.01 & 0.03 & 0.54 & 0.24 \\
\hline
\end{tabular}

Table 2 - Estimated spectral response of the components during the period of maximum precipitation. NIR ${ }^{1}$ - Near Infrared; MIR² - Middle Infrared.

\begin{tabular}{ccc}
\hline Spectral Bands & Equation & $\mathbf{r}^{\mathbf{2}} \mathbf{( N = 2 5 )}$ \\
\hline Blue & $r_{i}=0.0204+0.0712 x_{1}-0.0316 x_{2}$ & 0.74 \\
Red & $r_{i}=0.0194+0.1639 x_{1}+0.0096 x_{2}$ & 0.84 \\
NIR $^{1}$ & $r_{i}=0.0558+0.1625 x_{1}+0.4818 x_{2}$ & 0.72 \\
MIR $^{2}$ & $r_{i}=0.0317+0.3796 x_{1}+0.2058 x_{2}$ & 0.79 \\
\hline
\end{tabular}

Table 3 - Equation obtained by multiple linear regression and the coefficient of determination for the period corresponding to the maximum precipitation in each spectral band. NIR ${ }^{1}-$ Near Infrared; $M_{I} R^{2}-$

Middle Infrared.

\begin{tabular}{ccccc}
\hline \multicolumn{5}{c}{ August $\mathbf{2 0 1 5}$} \\
\hline \multirow{2}{*}{ Endmembers } & Blue & Red & NIR $^{1}$ & MIR $^{2}$ \\
\cline { 2 - 5 } & 0.02 & 0.02 & 0.04 & 0.01 \\
Shade & 0.06 & 0.14 & 0.37 & 0.40 \\
Soil & 0.02 & 0.04 & 0.49 & 0.25 \\
Vegetation & \multicolumn{5}{c}{ Spectral Bands } \\
\hline
\end{tabular}

Table 4 - Estimated spectral response of the components during the period of minimum precipitation. $N I R^{1}-$ Near Infrared; MIR ${ }^{2}$ - Middle Infrared.

\begin{tabular}{ccc}
\hline Spectral Bands & Equation & $\mathbf{r}^{\mathbf{2}} \mathbf{( N = 2 5 )}$ \\
\hline Blue & $r_{i}=0.0159+0,0413 x_{1}+0,0033 x_{2}$ & 0.77 \\
Red & $r_{i}=0.0193+0.1250 x_{1}++0.0175 x_{2}$ & 0.82 \\
NIR $^{1}$ & $r_{i}=0.0446+0.3229 x_{1}++0.4409 x_{2}$ & 0.79 \\
MIR $^{2}$ & $r_{i}=0.0122+0.3890 x_{1}+0.2374 x_{2}$ & 0.87
\end{tabular}

Table 5 - Equation obtained by multiple linear regression and the coefficient of determination for the period corresponding to the minimum precipitation in each spectral band. NIR 1 - Near Infrared; $\mathrm{MIR}^{2}-$

Middle Infrared.

Comparing the spectrum-temporal response of the targets analyzed in this study, as expected, it was observed that the peak of the vegetation component in the near infrared reached the highest value in February, coinciding with the period of maximum vegetative vigor due to rainfall. Inversely, lower values are seen in August, characterized by a drought period.

The performance of the method using fraction images was evaluated in two ways: (1) 


\section{LINEAR SPECTRAL MIXING MODEL APPLIED IN IMAGES FROM PROBA-V SENSOR: A SPATIAL MULTIRESOLUTION APPROACH}

comparing statistically the vegetation, soil, shade, and error fraction images obtained by the LSMM in the three applications and (2) comparing spatially and visually fraction images with information collected in the field campaign.

As a first LSMM performance evaluation method to estimate the spectral responses of endmembers in low spatial resolution images from the proportions in the higher spatial resolution images, it was performed the comparison of the average error obtained between the samples generated by this approach and the conventional approach (Table 6).

\begin{tabular}{|c|c|c|c|c|c|c|}
\hline & \multicolumn{3}{|c|}{ February 2015} & \multicolumn{3}{|c|}{ August 2015} \\
\hline & Estimated & Image & $100 \mathrm{~m}$ & Estimated & Image & $100 \mathrm{~m}$ \\
\hline Average Error & 0.48 & 0.60 & 0.51 & 0.49 & 0.59 & 0.52 \\
\hline
\end{tabular}

Error fraction images typically have lower values according to the accuracy of the models employed. Accordingly, the average error obtained by the approach proposed in this study was lower than that obtained by the conventional approach in both study periods. However, it is noteworthy that the highest average error for the moderate spatial resolution image may be associated to the fact that other components may be contained in pixel due to better spatial resolution. Thus, the number of components defined in this work may not be enough for the model used.
It is observed that the fraction images derived from the LSMM using the estimated endmembers by regression showed greater similarity to the fraction images derived from the better spatial resolution image when compared the average and the standard deviations (Table 7). In general, it is observed that the fraction images generated directly in the $1 \mathrm{~km}$ image were underestimated or overestimated in both periods and also showed higher standard deviation.

\begin{tabular}{|c|c|c|c|c|}
\hline \multicolumn{3}{|c|}{ February 2015} & \multicolumn{2}{|r|}{ August 2015} \\
\hline & $\begin{array}{l}\text { Average } \\
\text { Image }\end{array}$ & Standard deviation & $\begin{array}{c}\text { Average } \\
\text { Image }\end{array}$ & Standard deviation \\
\hline Shade & 0.46 & 0.46 & 0.23 & 0.11 \\
\hline Soil & 0.29 & 0.31 & 0.40 & 0.38 \\
\hline \multirow[t]{2}{*}{ Vegetation } & 0.51 & 0.27 & 0.36 & 0.35 \\
\hline & Estimated & & Estimated & \\
\hline Shade & 0.40 & 0.35 & 0.49 & 0.30 \\
\hline Soil & 0.25 & 0.23 & 0.38 & 0.33 \\
\hline \multirow[t]{2}{*}{ Vegetation } & 0.51 & 0.25 & 0.40 & 0.32 \\
\hline & $100 \mathrm{~m}$ & & $100 \mathrm{~m}$ & \\
\hline Shade & 0.24 & 0.17 & 0.57 & 0.27 \\
\hline Soil & 0.27 & 0.25 & 0.35 & 0.29 \\
\hline Vegetation & 0.50 & 0.24 & 0.41 & 0.23 \\
\hline
\end{tabular}

Table 7 - Average and standard deviation of components' proportions estimated by regression (Estimated) and generated in the conventional approach (100 $\mathrm{m}$ and Image). 


\section{LINEAR SPECTRAL MIXING MODEL APPLIED IN IMAGES FROM PROBA-V SENSOR: A SPATIAL MULTIRESOLUTION APPROACH}

Generally, the major differences were observed regarding the shade fraction image, assuming that the greater mixture of pixels due to the increase in areas susceptible to flooding during the rainy season may have overestimated both results using the product of $1 \mathrm{~km}$. According to Goltz et al. (2007), there are several forms of flooding that may occur in the Pantanal biome, both in temporary ponds and in areas previously established as vegetated, for example.

Regarding the variation of the components' proportions in relation to the seasonal variation in the Pantanal biome, what was to be expected for the study region is the increase in the proportion of both the vegetation and shade fraction during the rainy season and on the other hand, the highest influence of the soil in August due to the dry season.

Comparing quantitatively the proportions obtained in each pixel (Table 8), it was noted that the more suitable proportions were obtained using the $100 \mathrm{~m}$ image or the combination between products of different spatial resolutions.

\begin{tabular}{|c|c|c|c|c|}
\hline $\begin{array}{l}\text { Representation of pixel in } 1 \mathrm{~km} \text { (left) and } 100 \mathrm{~m} \\
\text { (right) }\end{array}$ & \multicolumn{4}{|c|}{ Proportion of the components } \\
\hline & & Image & Estimated & $100 \mathrm{~m}$ \\
\hline & Shade & 0.98 & 0.88 & 0.70 \\
\hline & Soil & 0.00 & 0.05 & 0.01 \\
\hline & Vegetation & 0.02 & 0.08 & 0.32 \\
\hline & Shade & 0.00 & 0.00 & 0.00 \\
\hline & Soil & 0.63 & 0.66 & 0.67 \\
\hline 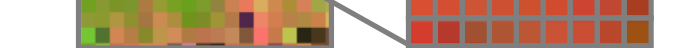 & Vegetation & 0.37 & 0.34 & 0.31 \\
\hline & Shade & 0.15 & 0.22 & 0.30 \\
\hline & Soil & 0.00 & 0.00 & 0.00 \\
\hline+ & Vegetation & 0.85 & 0.78 & 0.70 \\
\hline
\end{tabular}

Table 8 - Proportion of the components in the spatial resolution of $1 \mathrm{~km}$ and $100 \mathrm{~m}$ per pixel, where both estimated and image correspond to $1 \mathrm{~km}$ spatial resolution.

From the above, it was inferred that the combined use of a product with better spatial resolution allowed the user to improve the LSMM results as regards the determination of pixels that include a single reference member, since the result of the model depends directly on the choice of input parameters.

Regards the spatial and visual aspect, the fraction images can be used individually in gray scale or in colored compositions (RGB) for further analysis. It is noteworthy that the linear spectral mixing model is not a thematic classifier, but it provides data reduction and enhances the information contained in the pixel for several applications (SHIMABUKURO; PONZONI, 2017).

Thus, the fraction images obtained for the soil, vegetation and shade components derived of the last step are observed in Figure 6. This figure represents the detail of the PROBA-V products for better visualization of the results. It 


\section{LINEAR SPECTRAL MIXING MODEL APPLIED IN IMAGES FROM PROBA-V SENSOR: A SPATIAL MULTIRESOLUTION APPROACH}

is noticed that the components proportions in the fraction images (Figures $6 b, 6 c$ and $6 d$ ) are represented by the variation of the grayscale brightness - in the images. The level of dark gray represents a lower proportion of the component within the pixel and light gray level represents a highest proportion of the component within the pixel.

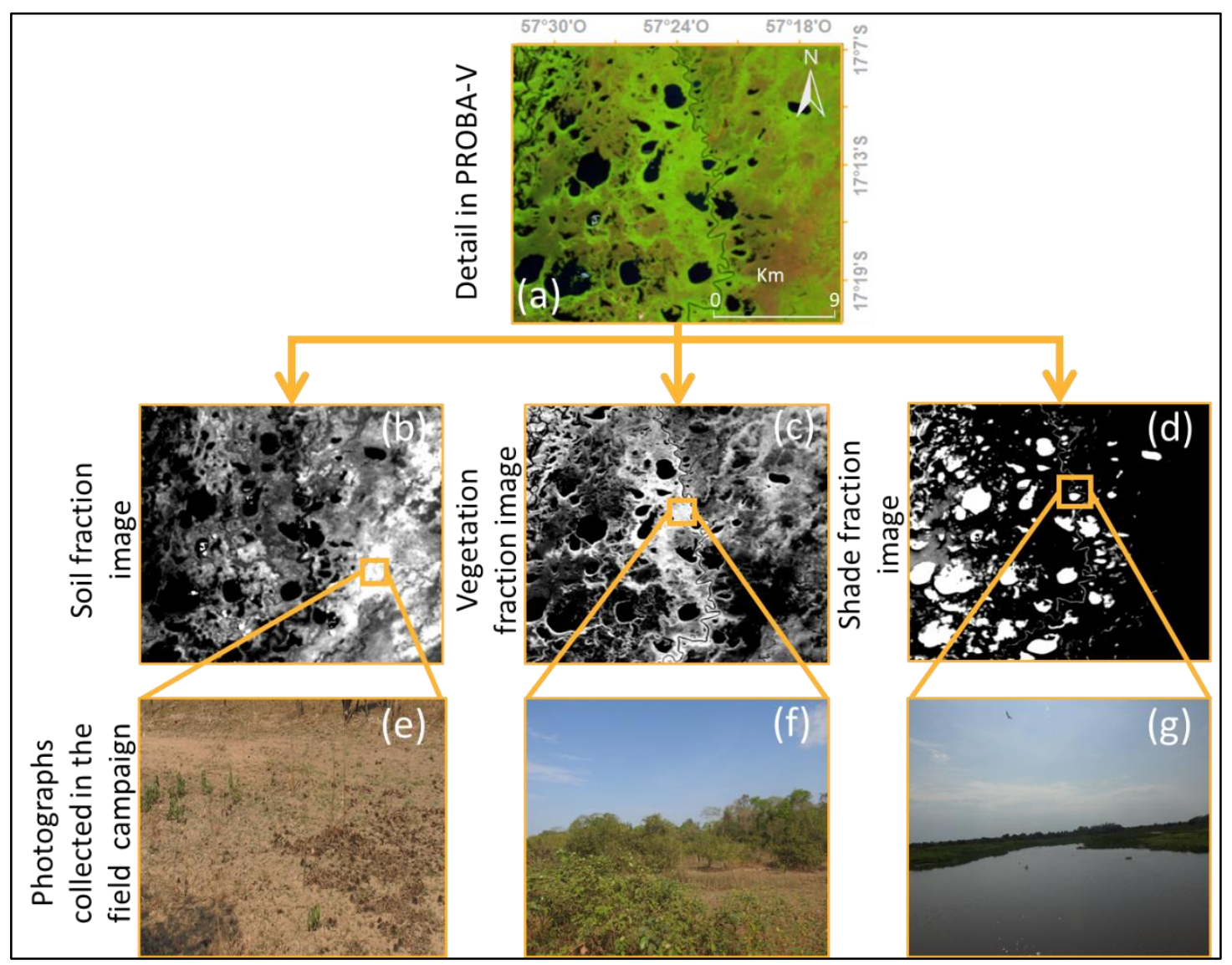

Figure 6 - (a) PROBA-V product details using false color composite of $R(1.603 \mu \mathrm{m}) \mathrm{G}(0.837 \mu \mathrm{m}) \mathrm{B}(0.655$ $\mu \mathrm{m}$ ) and (b) the respective fraction images of soil, (c) vegetation and (d) shade components derived from the LSMM in a small area of the Pantanal biome. The figures (e), ( $f$ ) and (g) show photographs collected in the field campaign, representing areas such as bare soil, vegetation, and water body, respectively, and thus the areas with higher brightness represent the highest proportion of a specific component within a pixel.

To validate the results, photographs collected in the field campaign were also used. Thus, Figures $\mathbf{6 e}, \mathbf{6 f}$ and $\mathbf{6 g}$ present details of soil, vegetation, and water body, clearly demonstrating the relationship between the presence of a specific target in the image and its enhancement in the fraction images. Thus, the soil fraction image contains information on bare soil. Vegetation fraction image shows variations in gray levels which may represent differences in vegetation types found in the Pantanal biome. Likewise, the shade fraction image highlights rivers and water bodies, making it possible the use in a multi-temporal scale to highlight the flooded areas in the biome.

One of the potentialities proposed in this paper is the possibility of extending the information contained in fraction images 
obtained at the local both on regional and global scales. Figure 7a shows a colored composition for the August month. The colors red $(R)$, green $(G)$, and blue (B) were respectively assigned to the soil, vegetation, and shade fraction images generated for the entire state of Mato Grosso using the $1 \mathrm{~km}$ PROBA-V product and endmembers estimated by combining the products. The color composition in Figure $\mathbf{7 b}$ and the grayscale fraction images in Figures $\mathbf{7 c}, \mathbf{7 d}$ and $7 \mathrm{e}$ represent the result to the Pantanal of Mato Grosso state in detail.

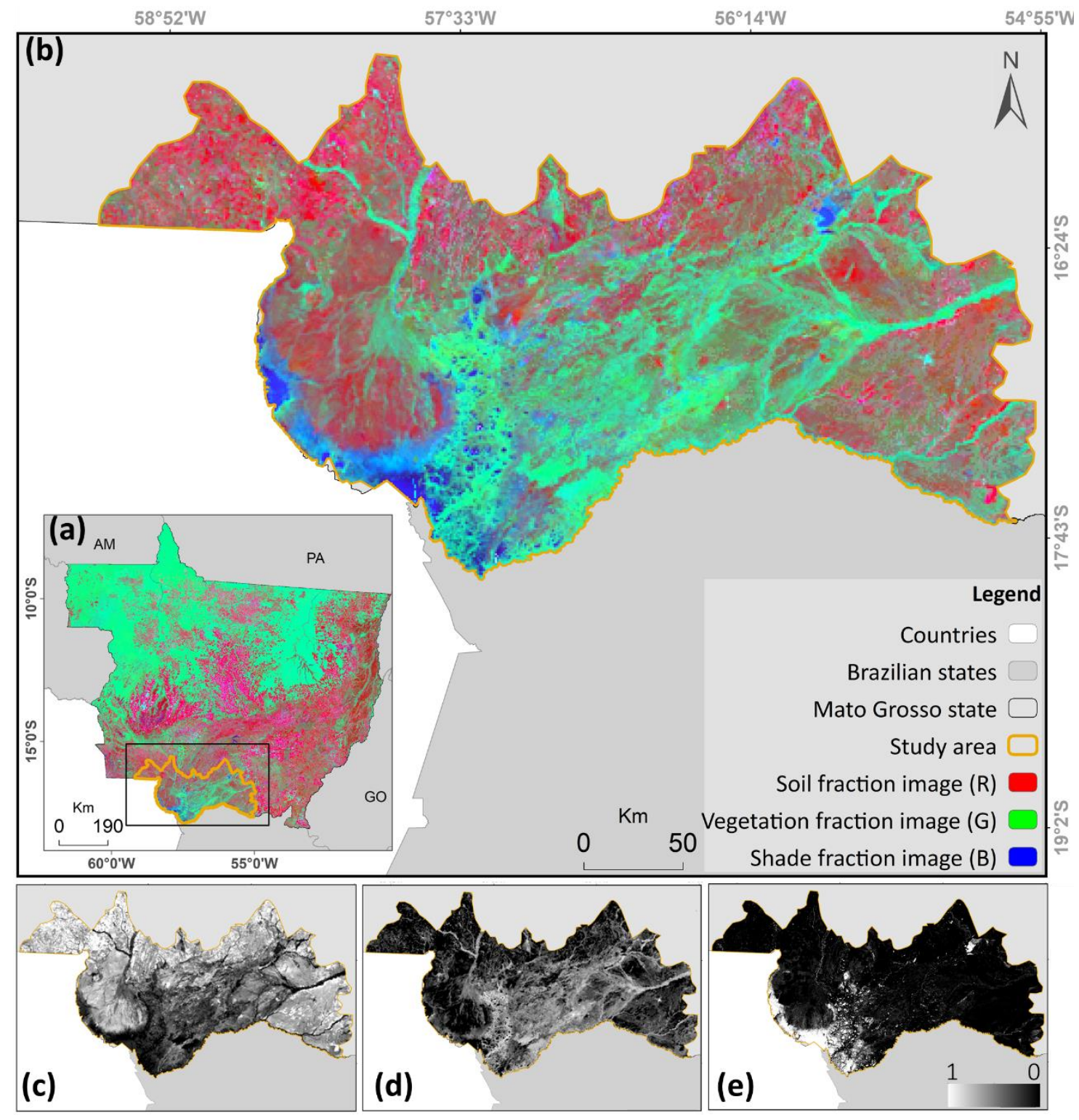

Figure 7 - (a) RGB composition using soil, vegetation and shade fraction images, respectively, derived from the LSMM and applied to the Mato Grosso state and (b) Pantanal of Mato Grosso in detail, using 1 $\mathrm{km}$ spatial resolution in August, 2015. (c), (d) and (e) individually represent the soil, vegetation, and shade fraction images in the biome, respectively, and the areas with higher brightness represent the highest proportion of the component within a pixel. 


\section{LINEAR SPECTRAL MIXING MODEL APPLIED IN IMAGES FROM PROBA-V SENSOR: A SPATIAL MULTIRESOLUTION APPROACH}

\begin{abstract}
Observing separately the colored composition (Figure 7a), there is an enhancement of the red areas with exposed soil. It is known that Mato Grosso is considered as one of the main producing states of cotton, soybeans, and corn in Brazil. The state's agricultural calendar shows the end of the cotton harvest in mid-August and September, the same time that the soil is prepared for corn and soybean cultivation (EMPAER, 2018). This fact justifies, for example, areas in red destined for agriculture and also areas without vegetation.
\end{abstract}

At the same time, the colored composition highlights vegetated areas in green, such as forested areas of the Amazon and in blue, the areas occupied by water bodies, especially observed in the limits of the Pantanal biome (Figure 7b). It is noteworthy that the variation in tones of the colored composition may be associated with different types of vegetation, soil and flood dynamics in the biome and in the state as a whole. Together, this information can aggregate the use of thematic classifiers to map land cover and land use in subsequent analyzes.

This work suggests that using the linear spectral mixing model to explore the combination of different spatial resolutions images, and then extending the information contained in fraction images on a local scale to extensive areas is a viable alternative. The method presented allows the use of the LSMM in low spatial resolution images, which are often used in regional and global studies, without the need to select pure pixels in the own image study, in view of the lower probability of finding them.

\section{CONCLUSIONS}

The technique used in this work demonstrates the potential of the linear spectral mixing model for linking information from sensors with different spatial and spectral resolutions. The analyzes allowed to observe that the spectral responses estimated improved the results regarding error, variability, and the identification of component proportions, since the undue choice of pixels considered as pure in low spatial resolution products may overestimate or underestimate the results.

Thus, one of the main applications for the use of this method is in the possibility of extending the information of fraction images contained in the local scale to studies on regional and global scales using a combination of different products. Moreover, it is also proposed to apply this method to products of different sensors with similar temporal resolutions.

\section{Acknowledgments}

The authors wish to express their gratitude to the National Institute for Space Research - INPE, to the support by the Fundação de Amparo à Pesquisa do Estado de São Paulo FAPESP (Processo No. 2016/19806-3) and by the National Research Council of Brazil - CNPq.

\section{REFERENCES}

Adami, M.; Bernardes, S.; Arai, E.; Freitas, R. M.; Shimabukuro, Y. E.; Espírito-Santo, F. D. B.; Rudorff, B. F. T.; Anderson, L. O. Seasonality of vegetation types of South America depicted by moderate resolution imaging spectroradiometer (MODIS) time series. International Journal of Applied Earth Observation and Geoinformation, v. 69, n. February, p. 148-163, 2018.

Adámoli, J. O Pantanal e suas relações fito geográficas com os Cerrados. Discussão sobre o conceito de "Complexo do Pantanal". In: Anais... CONGRESSO NACIONAL DE BOTÂNICA, 32, 1981, Teresina: Sociedade de Botânica do Brasil, 1982, p.109-119.

de Alcantara, E.H., Stech, J.L., de Moraes Novo, E.M.L., Shimabukuro, Y.E; Barbosa, C.C.F. Turbidity in the Amazon floodplain assessed through a spatial regression model applied to fraction images derived from MODIS/Terra. IEEE Transactions on Geoscience and Remote Sensing, v. 46, n. 10, pp.2895-2905, 2008.

Asner, G. P. Cloud cover in landsat observations of the Brazilian Amazon. International Journal of Remote Sensing, v. 22, n. 18, p. 3855-3862, 2001. 


\section{LINEAR SPECTRAL MIXING MODEL APPLIED IN IMAGES FROM PROBA-V SENSOR: A SPATIAL MULTIRESOLUTION APPROACH}

Baret, F.; Weiss, M.; Lacaze, R.; Camacho, F.; Makhmara, H.; Pacholcyzk, P.; Smets, B. Geov1: $\angle A I$ and FAPAR essential climate variables and FCOVER global time series capitalizing over existing products. part1: principles of development and production. Remote Sensing of Environment, v. 137, p. 299-309, 2013.

Caten, A. T.; Benvegnu, D. J. C.; Robaina, A. D. Qualidade em levantamentos com GPS através da modelagem da acurácia e da precisão. Revista Brasileira de Agrociência, ISSN 0104-8996, v. 13, n. 2, 243-248, 2007.

CPTEC - Centro de Previsão de Tempo e Estudos Climáticos. Monitoramento Climático Mensal e Sazonal das Chuvas no Brasil na Página CPTEC/INPE, 2014. Disponível em: http://clima1.cptec.inpe.br/evolucao/pt.

De Freitas, R. M.; Haertel, V.; Shimabukuro, Y. E. Modelo linear de mistura espectral em imagem de moderada resolução espacial. Boletim de Ciências Geodésicas, v. 14, n. 1, p. 55-71, 2008.

EMPAER - Empresa Mato-Grossense de pesquisa, assitencia e extensão rural. "Calendário Agrícola", 2018.

Disponível em:httphttp://www.empaer.mt.gov.br/documen ts/8024815/1016

0349/Calend\%C3\%A1rio+Agr\%C3\%ADcola+2018/ 7b605d93-2fc3-1f13-d62e4bbe8d75e0aa.

Galvão, L. S.; Pereira Filho, W.; Abdon, M. M.; Novo, E. M. M. L.; Silva, J. S. V.; Ponzoni, F. J. Spectral reflectance characterization of shallow lakes from the brazilian pantanal wetlands with field and airborne hyperspectral data. International Journal of Remote Sensing, v. 24, n. 21, p. 4093-4112, 2003.

García-Haro, F.J., Sommer, S. and Kemper, T. Variable multiple endmember spectral mixture analysis (VMESMA): a high-performance computing and environment analysis tool. International Journal of Remote Sensing. v. 26, n. 10, 2135-2162, 2005.
Goltz, E.; Brandão, D.; Tomás, L.; Mantelli, L. R.; Adami, M.; Shimabukuro, Y. E.; Formaggio, A. R. Utilização de índices espectrais de vegetação do sensor MODIS na determinação de áreas suscetíveis a alagamento no Pantanal Sul Matogrossense. Revista Brasileira de Cartografia. v. 59, n. 1, 80-94, 2007.

Harris, M. B.; Tomas, W.; Mourão, G.; Da Silva, C. J.; Guimarães, E.; Sonoda, F.; Fachim, E. Safeguarding the pantanal wetlands: threats and conservation initiatives. Conservation Biology, v. 19, n. 3, p. 714-720, 2005.

Hilker, T., Wulder, M.A., Coops, N.C., Linke, J., McDermid, G., Masek, J.G., Gao, F.; White, J.C. A new data fusion model for high spatial-and temporal-resolution mapping of forest disturbance based on Landsat and MODIS. Remote Sensing of Environment, v. 113, n. 8, pp. 1613-1627, 2009.

Keshava, N. and J. F. Mustard. 2002. Spectral Unmixing. IEEE Signal Processing Magazine, 19 (1): 44-57. doi:10.1109/79.974727.44-57.

Li, W.; Baret, F.; Weiss, M.; Buis, S.; Lacaze, R.; Demarez, V.; Dejoux, J. Francois; Battude, M.; Camacho, F. Combining hectometric and decametric satellite observations to provide near real time decametric fapar product. Remote Sensing of Environment, v. 200, p. 250-262, 2017.

Meyer, T.; Okin, G. S. Evaluation of spectral unmixing techniques using MODIS in a structurally complex savanna environment for retrieval of green vegetation, nonphotosynthetic vegetation, and soil fractional cover. Remote Sensing of Environment, v. 161, p. 122-130, 2015.

Padovani, C. R.; Vettorazzi, C. A.; Shimabukuro, Y. E.; Adami, M.; Freitas, R. M. De. Estudo das inundações do pantanal a partir de imagens modis. In: Anais...ANAIS XIV SIMPÓSIO BRASILEIRO DE SENSORIAMENTO REMOTO, XIV, 2009, Natal: INPE, 2009, p. 4805-4812. 


\section{LINEAR SPECTRAL MIXING MODEL APPLIED IN IMAGES FROM PROBA-V SENSOR: A SPATIAL MULTIRESOLUTION APPROACH}

Ravaglia, A. G.; Cristini, L.; Silva, F.; Santos, S. A.; Shimabukuro, Y. E.; Pellegrin, L. A.; Soriano, B. M.; Aguiar, G. Uso de um modelo linear de mistura espectral e índice de vegetação na avaliação de pastagens em degradação no pantanal. Anais...V SIMPOSIO SOBRE RECURSOS NATURAIS E SOCIOECONOMICOS DO PANTANAL, 5, 2010, Corumbá: EMBRAPA Pantanal, p. 1-5, 2010.

Richardson, A. J.; Wiegand, C. L.; Gausman, H. W.; Cuellar, J. A.; Gerbermann, A. H. Plant, soil, and shadow reflectance components of row crops. Photogrammetric Engineering Remote Sensing, v. 41, n. 11, p. 1401-1407, 1975.

Shimabukuro, Y.E., Arai, E., Duarte, V., Jorge, A., Santos, E.G.D., Gasparini, K.A.C. and Dutra, A.C. Monitoring deforestation and forest degradation using multi-temporal fraction images derived from Landsat sensor data in the Brazilian Amazon. International Journal of Remote Sensing, pp.1-22, 2019.

Shimabukuro, Y.E; Ponzoni, F.J. Mistura espectral: modelo linear e aplicações. São Paulo: Oficina de Textos, ISBN 978-85-7975-270-4, 2017.

Shimabukuro, Y.E., R. Beuchle, R. Grecchi and Achard, F. Assessment of forest degradation in Brazilian Amazon due to selective logging and fires using time series of fraction images derived from Landsat ETM+ images". Remote Sensing Letters, 5 (9), 773-782, 2014.

Shimabukuro, Y. E.; Novo, E. M.; Ponzoni, F. J. Índice de vegetação e modelo linear de mistura espectral no monitoramento da região do pantanal. Pesquisa Agropecuaria Brasileira, v. 33, n. SUPPL. 2, p. 1729-1737, 1998.

Shimabukuro, Y. E.; Smith, J. A. Fraction images derived from Landsat TM and MSS data for monitoring reforested areas. Canadian Journal of Remote Sensing, v. 21, n. 1, p. 67-74, 1995.

Shimabukuro, Y. E.; Smith, J. A. The least-squares mixing models to generate fraction images derived from remote sensing multispectral data. IEEE Transactions on Geoscience and Remote Sensing, v. 29, n. 1, p. 16-20, 1991.
Silio-Calzada, A.; Barquín, J.; Huszar, V. L. M.; Mazzeo, N.; Méndez, F.; Álvarez-Martínez, J. M. Long-term dynamics of a floodplain shallow lake in the Pantanal wetland: is it all about climate?. Science of the Total Environment, v. 605-606, p. 527-540, 2017.

Silva, J. D. S. V. Da; Abdon, M. D. M. Delimitaçao do pantanal brasileiro e suas sub-regiões. Pesquisa Agropecuária Brasileira, v. 33, $\mathrm{n}$. Especial, p. 1703-1711, 1998.

Wolters, E.; Dierckx, W.; lordache, M.-D.; Swinnen, E. PROBA-v products user manual v3.01. Image (rochester, n.y.), n. C, p. 1-110, 2018.

Wulder, M.A., White, J.C., Goward, S.N., Masek, J.G., Irons, J.R., Herold, M., Cohen, W.B., Loveland, T.R.; Woodcock, C.E. Landsat continuity: Issues and opportunities for land cover monitoring. Remote Sensing of Environment, v. 112, n. 3, pp. 955-969, 2008.

Zhang, Y., Li, X., Ling, F., Atkinson, P.M., Ge, Y., Shi, L.; Du, Y. Updating Landsat-based forest cover maps with MODIS images using multiscale spectral-spatial-temporal superresolution mapping. International Journal of Applied Earth Observation and Geoinformation, v. 63, pp. 129142, 2017.

Zhu, Z.; Woodcock, C. E. Automated cloud, cloud shadow, and snow detection in multitemporal landsat data: an algorithm designed specifically for monitoring land cover change. Remote Sensing of Environment, v. 152, p. 217-234, 2014. 